IBIMA Publishing

Journal of Internet Social Networking \& Virtual Communities

http://www.ibimapublishing.com/journals/JISNVC/jisnvc.html

Vol. 2012 (2012), Article ID 313585, 14 pages

DOI: $10.5171 / 2012.313585$

\title{
Social Media - Is It Worth the Trouble?
}

\author{
Iris Uitz
}

Graz University of Technology, Institute of Business Economics and Industrial Sociology, Graz, Austria

\begin{abstract}
Marketing environment has changed due to the advent of the internet, the subsequent globalization and the hence ensuing greater competition. These environmental dynamics cause serious challenges for marketers. First, a strong marketing orientation is more important than ever to promote products and services successfully. It is also essential for engaging with customers, and for building brand recognition. Second, new channels, such as social media platforms, are added to the traditional marketing channels. Third, the pressure on marketing managers to justify their marketing allocation and spending is rising. To support managers in their marketing investment decisions, measurement metrics have become indispensable. Based on an investigation of recent studies and public sources this paper presents various approaches to marketing measurement metrics, especially social media marketing metrics.
\end{abstract}

Keywords: Marketing management; Marketing metrics; Return on marketing; Social media.

\section{Introduction}

Media such as newspapers, radio and television have dominated the 20th century and still do so. Social behavior and thinking patterns have traditionally been spread via these media. However, a new trend has evolved: social media. Although it still seems to be in its infancy, social media is on the rise. Facebook, Google+, Twitter, YouTube \& Co. are just a few examples of successful social media applications that are already used by millions of people. In fact, the number of users is steadily increasing. Social networking, however, is not new. It has always existed. It is within human nature to socialize and to communicate, either to comment, recommend or alert each other. With the advent of the internet and the globalization that came along with it, social media was introduced and social networking became much faster. The adoption of these social tools has been the fastest growing trend in corporate history and it is significantly changing the way organizations interact with their constituent groups. In the early phases of the internet evolution, in the mid 90's, Hoffman and Novak (1995) published a paper in which they presented a conceptual foundation of marketing practice in computer-mediated environments. They introduced marketers to the revolutionary changes that hey expected to occur in the way companies interact with their customers due to the rise of the internet. And they were right. The openness of the internet was and still is a clear factor in fostering competition and innovation. With the rise of new communication technologies and channels, which are commonly termed Web 2.0 or social media, the web has become more flexible. Moreover, the static website with its one-way communication has turned into a two way communication tool. Web 2.0 and especially social media have opened new ways to communicate, collaborate, share content and advertise online. Thus, the effectively passive audience has gained new opportunities to interact. Simply said, social media has enabled a dialogue and discovery around the content. Hoffman and Novak (1995) already anticipated that the

Copyright (C) 2012 Iris Uitz. This is an open access article distributed under the Creative Commons Attribution License unported 3.0, which permits unrestricted use, distribution, and reproduction in any medium, provided that original work is properly cited. Contact author: Iris Uitz E-mail: Austria, iris.uitz@tugraz.at 
"consumer will be an active participant in an interactive exercise of multiple feedback loops and highly immediate communication."

A digital-advertising study, carried out by McKinsey (2008), revealed that ninety one percent of marketing executives are advertising online. Limited resources and also the economic crisis lead to pressure on the marketing budget. More than half of the interviewees were cutting their expenditures on traditional media in order to shift it to the online marketing budget (McKinsey, 2008). These environmental dynamics cause serious challenges for marketers and the pressure to justify marketing allocations and spending rises. In times of information overload and austerity measures on the companies' side, measuring marketing investments is of particular importance to support managers in their marketing investment decisions (Seggie, Cavusgil and Phelan, 2007). According to Bughin, Shenkan and Singer (2008) the development of measurement tools failed to keep pace with the development of the digital world. Managers often use social media and do not have any strategy or knowledge of the precise financial or non-financial returns on marketing investment. Accurate techniques and metrics that are capable of measuring financial and non-financial impacts of marketing decisions will help to understand the true impact of marketing investments (Petersen et al., 2009; Seggie, Cavusgil and Phelan, 2007). The relevance of using such metrics is well known among practitioners. However, models that link marketing activities to quantifiable financial outcome and manuals that state which metrics to use and how to apply them are scarce in literature (Ambler and Kokkinaki, 1997; Ambler, Kokkinaki and Puntoni, 2004; Davis, 2007; Kokkinaki and Ambler, 1999; 2009; Lenskold, 2003; Llonch, Eusebio and Ambler, 2002; Petersen et al., 2009; Powell, 2002; Seggie, Cavusgil and Phelan, 2007). The outcome of marketing activities often involves multiple factors. Since many of the benefits are indirect and can also depend on subjective evaluation, measuring an exact impact is very complex
(Llonch, Eusebio and Ambler, 2002; Petersen et al., 2009; Seggie, Cavusgil and Phelan, 2007; Sampaio et al. 2010).

This paper discusses various approaches to deriving a return on marketing and especially social media marketing investment. Thereby I focus on listing several measurement metrics that assist managers in evaluating and optimizing marketing investments, rather than on calculation.

Using social media becomes more and more popular and expensive, both in terms of time and money. Therefore, the question of how effective social media is versus the resources needed to maintain the effort arises.

\section{Definition of Web 2.0 and Social Media}

The terms 'Web 2.0' and 'social media' are two of the most common words in modern IT. Often used interchangeably, a distinction has to be made.

In its infancy, the Web was primarily an information medium that provided search engines for the efficient and effective retrieval of globally dispersed information. In recent years this has changed. The Web has become a social place that enables people to network and communicate worldwide. Web 2.0 is a new form of internet, where users actively participate in the development of content and appearance. It is generally associated with network-based platforms upon which social media applications and tools run or function. The term Web 2.0 was coined by Tim O'Reilly (2005), who calls the Web 2.0 a "business revolution in the computer industry caused by the move to the internet as a platform, and an attempt to understand the rules for success on that new platform. Chief among those rules is this: Build applications that harness network effects to get better the more people use them. (O'Reilly 2005)" The neologism describes a second generation of web-based services that allows users more than just to retrieve information. They rely on the interactive possibilities of "Web 1.0" to 
provide "Network as platform" computing that allows users to run software applications entirely through a browser. Web 2.0 does not have a hard boundary but rather a set of principles for sites that adhere to one or more of the principles. According to War (2005) the definition of Web 2.0 has eight core patterns: (1) Harnessing collective intelligence, (2) Data as the next 'Intel inside', (3) Innovation in assembly, (4) Rich user experience, (5) Software about the level of a single device, (6) Perpetual beta, (7) Leveraging the long tail, and (8) Lightweight software and business models and cost effective scalability. Web 2.0 aims to build not only online website but event-driven user experience.

Social media, i.e. the use of web-based and mobile technologies/applications for social interaction, developed out of the Web 2.0. It encompasses a large number of tools for online communication (e.g. texts, wikis, blogs, internet forums and social network services). As a consequence, social media influences various aspects of consumer behavior such as awareness, purchase behavior and post-purchase communication and evaluation. According to Ebersbach (2008), social media is defined as (a) a webbased application, (b) for people, (c) to exchange information (d) and build relationships as well as maintain their collaborative communication and cooperation. Social media therefore comprises Web 2.0 services that allow participants to create their own content and exchange this generated content with other participants. The interaction involves the mutual exchange of information, opinions, impressions and experiences. The users actively comment, rate or recommend the content, and social networks and social relationships can thereby evolve. The line between producer and consumer is thus blurring.

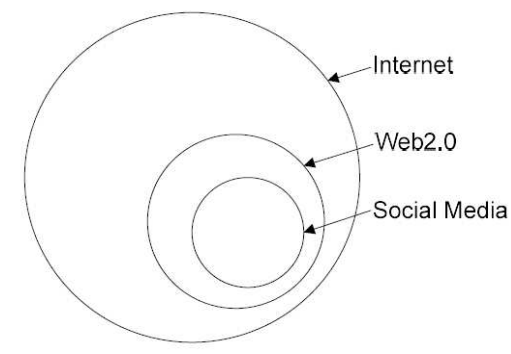

Fig 1. Distinction between Internet, Web 2.0 and Social Media

\section{Measuring Marketing Performance}

Marketing performance measurements have recently received significant attention from both scholars and practitioners. Traditionally, market return metrics, such as market share and sales volume, were dominantly used for indicating marketing performance (Gruca and Rego, 2005). The latest literature mentions a wide spectrum of indicators. Ambler and Riley (2000) noted a total of 38 key metrics on measuring marketing effectiveness, Clark (1999) found 20, and Davidson (1999) proposed $10 \mathrm{key}$ metrics on marketing measurability. Some authors attempted to structure the found metrics into categories. Kokkinaki and Ambler (1999), for example, proposed six metric classifications: (1) financial measures (e.g. sales, profit, turnover, contribution margins), (2) measures of competitive market (e.g. market share, advertising share, and promotion share), (3) measures of consumer behavior (e.g. customer penetration, customer loyalty, and number of new customers), (4) measure of consumer intermediate (e.g. brand recognition, and customer satisfaction), (5) measures of direct customer (e.g. distribution level, profitability of intermediaries, and quality of service), and 
(6) measures of innovativeness (e.g. new products launched and revenue of these products as a percentage of total turnover). Clark (1999) downsized the categories to four: (1) traditional financial measures (e.g. sales revenue, profit, and cash flow), (2) nonfinancial measures (e.g. customer loyalty and satisfaction, quality of service, adaptability, and market share), (3) input measures related to marketing (e.g. marketing assets, audits and implementation), (4) output measures (e.g. effectiveness and efficiency, and multivariate analysis). Among practitioners the set of nine metric groups of Farris, Bendle, Pfeifer, and Reibenstein (2006) is widely used: (1) share of hearts, minds and markets, (2) margins and profits, (3) product and portfolio management, (4) customer profitability, (5) sales force and channel management, (6) pricing strategy, (7) promotion, (8) advertising media and web metrics, and (9) marketing and finance.

Since scholars have expressed concern that marketing metrics very often are not linked to quantifiable financial output, Seggie, Cavusgil and Phelan (2007) examined existing approaches to monitor marketing performance and rated them according to seven dimensions, which marketing metrics should evolve. Table 1 gives an overview of their ratings.

Table 1: Existing Approaches to Measurement Critiqued on Seven Dimensions (Seggie et al. 2007)

\begin{tabular}{|l|l|l|l|l|l|l|}
\hline & EVA & $\begin{array}{l}\text { Balanced } \\
\text { scorecard }\end{array}$ & $\begin{array}{l}\text { Brand } \\
\text { equity } \\
\text { (financial } \\
\text { perspective) }\end{array}$ & $\begin{array}{l}\text { Brand } \\
\text { equity } \\
\text { (consumer } \\
\text { psychology } \\
\text { perspective) }\end{array}$ & $\begin{array}{l}\text { Relational } \\
\text { equity }\end{array}$ & $\begin{array}{l}\text { Customer } \\
\text { equity }\end{array}$ \\
\hline Financial & Yes & Partial & Yes & No & Partial & Yes \\
\hline $\begin{array}{l}\text { Forward } \\
\text { looking }\end{array}$ & No & Partial & Yes & No & Partial & Yes \\
\hline Long-term & No & Partial & Yes & Partial & Partial & Yes \\
\hline Micro & No & No & No & Partial & No & Yes \\
\hline Relative & No & No & No & No & No & No \\
\hline Causal & No & No & No & No & No & Yes \\
\hline Objective & Yes & Partial & Yes & No & Partial & No \\
\hline
\end{tabular}

Economic Value Added (EVA) is still seen as one of the advanced traditional accounting metrics and therefore widely used. Even though it is financially-based and objective, it has weaknesses according to the framework developed by Seggie, Cavusgil and Phelan (2007). The balance scorecard by Kaplan and Norton (1992) helps managers to get a comprehensive overlook of the whole organization. Within their framework, the customer perspective, the innovation and learning perspective, the internal business perspective as well as the financial perspective is reproduced. Although it ensures partially financial-measures, it fails to derive direct impact of marketing actions. Aaker (1991, 1996) and Keller (1993) proposed widely accepted models for the measurement of brand equity. Aaker's model for the measurement of loyalty, considers perceived quality brand associations and brand awareness.

Keller added the dimension of brand image. Depending on whether the measure is subjective or objective financial aspects can be measured. The Relational Equity Scorecard, a model that combines the Relational Maturity Model with a scorecard approach, provides measures on the quality of partnerships. According to the framework, customer equity seems to be a feasible metric to link marketing investment to the increase of all customer lifetime values. 
Some practitioners still stick to the oldfashioned and common financial metric return on investment (ROI). The ROI determines the value of an investment by setting the return or benefits resulting from an action in relation to the expenditure or invested resources.

Apart from a discussion whether ROI or cost effectiveness is more appropriate, Likely, Rockland and Weiner (2006) also present several return models such as (1) Return on Impressions model, (2) Return on Media impact model, (3) Return on target influence model, and (4) Return on earned media model.

As Barwise and Farley (2004) recommend, the success of marketing performance and the measurement of that always lies in the combination of different metrics rather than the single use on one specific.

\section{Measuring Social Media Performance}

Since the rise of social media, it has become common among marketers to talk about social media activities. It is not only the number of users that has increased, but there is also a growing number of social media applications, which are struggling for new users. The applications have different technology perspectives and therefore also vary in their functionality and their mode of utilization. The specific purpose determines which type of social media to use and how the customers react and respond to it. Although Social media in our everyday language is mostly used for socialnetworking services, especially Facebook, Google+ and Twitter, a vast variety of Social media services exist (see Figure 2).

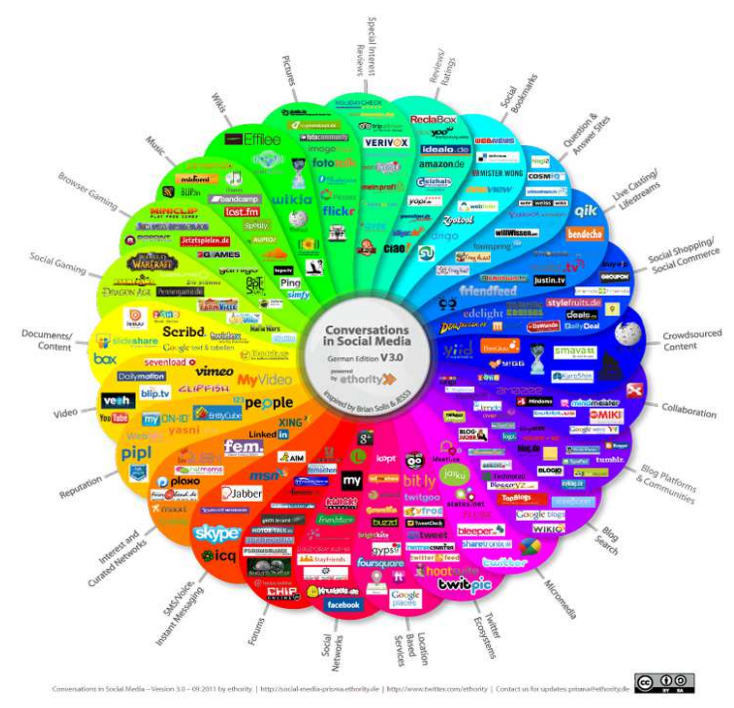

Fig 2. Social Media Prisma (Ethority GmbH \& Co. KG, 2012)

In the literature no common classification of social media tools and applications can be found. Safko (2010), for example, divides the social media world into 15 categories (social networking, publish, photo sharing, audio, video, microblogging, livecasting, virtual worlds, gaming, productivity applications, aggregators, RSS, search, mobile, interpersonal). This paper concentrates on the most commonly used social media platforms: (1) Social networking Sites (e.g., Facebook, Google+, LinkedIn, MySpace), (2) Blogs (e.g. Blogger, Wordpress), (3) Microblogging (e.g., Twitter), (4) Social bookmarking sites (e.g., delicious) and (5) Sharing Sites (e.g., Flickr, You Tube). Before 
addressing relevant metrics for social media applications, an introduction of the above mentioned applications and platforms is necessary.

A simple understanding of the services does not only lead to the success of a Social media marketing strategy for a company. Social media services just provide a platform to support and promote communication. The firms' purpose and strategy determines which type of social media to use. Marketing Sherpa (2010) has created a three dimensional chart which maps different social media tools. The three dimensions are data breakouts for the use, effort required (both in time and resources) and effectiveness.

Thus, figure 3 shows, for example, that social networks are often used, require little effort and are of medium effectiveness. The effort usually determines the use of social media more than the effectiveness. Especially in the beginning the focus is on "fast and easy". The more effort required, the less likely is the implementation of the social media application.

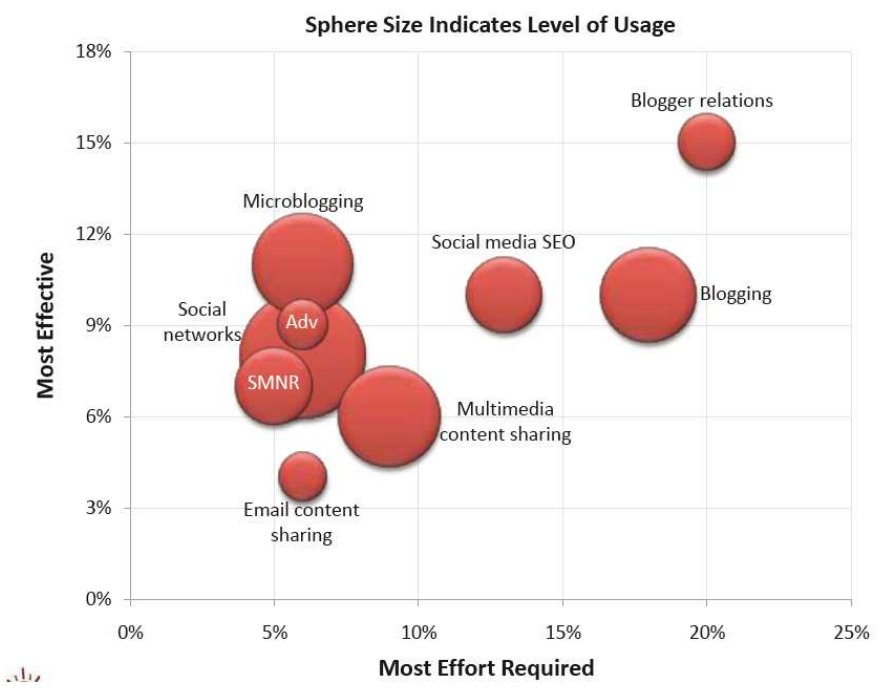

Fig 3. Three Dimensions of Social Marketing Tactics (Marketing Sherpa, 2010)

Before addressing different social media metrics, the most relevant applications for companies are briefly described.

1) Social Networking Sites: The Small World Phenomenon by Milgram (1967) states that on average every person shares six friends with every other person. Computer simulations demonstrated that if you combine six billion points (i.e. the population of the earth) in an accurate way one can pass from any point to any other point only via a maximum of six nodes. Social networking sites are online sites, platforms or services that focus on building social networks or relations among people. Individuals, groups or companies can set up a profile and connect with others. Consumers often rate the value of the network by the number of friends and their engagement, whereas marketers evaluate the endorsement of the consumers by counting the number of friends, followers and subscribers and their contribution to viral distribution.

2) Blogs: A weblog or blog is a web site on which individuals, groups or business entities can publish news, opinions and commentaries various topics. Many blogs focus on a particular subject or current 
event whereas others cover a niche topic or are similar to a personal online diary. Usually new posts are listed at the top, older ones follow.

3) Microblogging (e.g. Twitter) features very short posts in a maximum of 140 characters and can be received in various ways.

4) Social bookmarking sites (e.g. Delicious): Social bookmarking helps to organize, store and manage online resources.

5) Sharing Sites: Some platforms offer users the possibility to store and share photos (e.g. Picasa, Flickr), videos (e.g. YouTube), slides (e.g. SlideShare) and other media with other user, both for public and private use.

In nowadays businesses budgets are tight und marketers are under pressure. They need to be sure to get a return on their investments and to justify the used marketing mix to the executive board. Like 'traditional marketing metrics', social media metrics are not only quantitative. What is the value of a customer attitude?

The measurement of social media marketing performance indicators is very complex and has to deal with numerous variables. Isolating single dimensions and calculating the specific impact is hardly possible. Furthermore, each social media activity has a specific goal and therefore a different measurement metric. Some attributes may stay the same, but the combination will be different. According to Owyang and Lovett (2006), if you do not have a goal then you cannot measure it. Social media is a bidirectional communication between the company and people/followers. Therefore, it is not only essential to measure how many consumers engage but also how high the activity level is. Also note that not only satisfied customers post their comments, but also dissatisfied customers express their resentment. Tracking the tone and perception as well as reacting immediately encompasses trust and customer loyalty. Brand monitoring solutions enable to surveil discussions of the brand and to track the sentiments. Nevertheless, interpreting written statements is often difficult and subjective. Hoffmann and Fodor (2010) recommend to consider four key motivations of consumers, also called the ' $4 c$ 's'. With creating and consuming content, consumers connect online with other consumers and thereby control not only their own actions but also the market.

According to the general marketing performance measurement literature companies also still measure consumer loyalty and growth prospects with the change in the Net Promotor Score (NPS) (Reichheld, 2003). The concept of NPS is much more than just an analysis to determine customer satisfaction. It also has a strategic component. Ideally, any company decision should lead to an increased NPS in the long term. Through a customer survey the NPS directly measures the probability with which a customer expresses a recommendation for the company / product / service. It is calculated by taking the total percentage of technology users who are promotors and subtracting the total percentage who are detractors. Passively satisfied remain unconsidered. Promotors are those customers, scoring $9-10$ on a 10 likert scale who are loyal enthusiasts and therefore will keep buying. Passives (score 78) are satisfied but unenthusiastic customers who are vulnerable to competitive offerings. Detractors (score 0-6) are unhappy customers who can damage your brand and impede growth through negative word-ofmouth. The NPS therefore ranges from plus 100 to minus 100. The NPS serves as a decision support of social media impact, for it shows how much a company would need to pay to achieve a similar outcome. Studies have shown a strong correlation between recommendation, customer satisfaction and customer loyalty. A financial outcome cannot be gauged; changes in NPS, however, relate to revenue growth. 
A similar concept is the Advertising Value Equivalency (AVE) (Likely, Rockland and Weiner, 2006), also known as "Return on earned media". By considering opportunity costs, earned media and the costs of advertising, a comparison metric affirms whether a dollar spent on media relations publicity is more or less effective than a dollar spent on advertising.

The ROI (Return on Investment) usually plays an important role in investment decisions. Measuring an ROI in Social media, however, is very difficult. "The problem with trying to determine ROI for social media is you are trying to put numeric quantities around human interactions and conversations, which are not quantifiable." (Jason Fall, 2008) The collection of costs and benefits incurred as a result of social media investments genuine factual figures. In social media marketing, the first result is always the communication, the resulting conversations and relationships. Instead of the "Return on Investment", the ROI in Social media marketing is commonly referred to as "Return on Influence" or "Return on Interaction".

Peters (2010) suggests the following ways to measure social media efforts: (1) awareness, (2) engagement and (3) revenue, whereas Hoffmann and Fodor (2010) focus on three (mainly qualitative) objectives: (a) brand awareness, (b) brand engagement, and (c) word of mouth. Social media can enhance brand awareness in various ways. The decisive question is: (a) "How many consumers are you reaching?" (b) If people involve in social media activity, brand engagement can establish, the commitment to the brand arises and hence consumers are more motivated to support the brand, which will reinforce loyalty to the brand. (c) Once consumers are aware and engaged they pass their opinions to others. Table 2 lists several key metrics according to their social media application and objectives. 
Table 2: Key Metrics for Social Media Applications (Adapted from Hoffman and Fodor, 2010)

\begin{tabular}{|c|c|c|c|}
\hline $\begin{array}{l}\text { SOCIAL MEDIA } \\
\text { APPLICATION }\end{array}$ & BRAND AWARENESS & BRAND ENGAGEMENT & WORD OF MOUTH \\
\hline Social Networks & $\begin{array}{l}\text { number of } \\
\text { members/fans } \\
\text { number of installs of } \\
\text { applications } \\
\text { number of page views } \\
\text { number of impressions } \\
\text { number of bookmarks } \\
\text { number of } \\
\text { reviews/ratings and } \\
\text { valence +/- }\end{array}$ & $\begin{array}{l}\text { number of comments } \\
\text { number of active users } \\
\text { number of "likes" on } \\
\text { friends' feed } \\
\text { number of user-generated } \\
\text { items } \\
\text { usage metrics of } \\
\text { applications/widgets } \\
\text { impressions-to- } \\
\text { interactions ratio } \\
\text { rate of activity (how often } \\
\text { members personalize } \\
\text { profiles, bios, links etc.) }\end{array}$ & $\begin{array}{l}\text { frequency of } \\
\text { appearances in } \\
\text { timeline of friends } \\
\text { number of posts on } \\
\text { wall } \\
\text { number of } \\
\text { resposts/shares } \\
\text { number of responses } \\
\text { to friends referral } \\
\text { invites }\end{array}$ \\
\hline Blogs & $\begin{array}{l}\text { number of unique } \\
\text { visitors } \\
\text { number of return visits } \\
\text { page views } \\
\text { number of times } \\
\text { bookmarked } \\
\text { author credibility } \\
\text { conversation density } \\
\text { search engine ranking } \\
\text { number of blog-driven } \\
\text { stories by offline-press, } \\
\text { Web media or high } \\
\text { profile bloggers }\end{array}$ & $\begin{array}{l}\text { number of members } \\
\text { number of RSS feed } \\
\text { subscribers } \\
\text { number of comments } \\
\text { amount of user-generated } \\
\text { content } \\
\text { average length of time on } \\
\text { site } \\
\text { number of responses to } \\
\text { polls, contests, surveys } \\
\text { content freshness }\end{array}$ & $\begin{array}{l}\text { number of } \\
\text { references to blog in } \\
\text { other media } \\
\text { (online/offline) } \\
\text { number of in-links } \\
\text { and out-links } \\
\text { number of people } \\
\text { commenting on blog } \\
\text { number of reblogs } \\
\text { number of log posts } \\
\text { in a Technorati } \\
\text { search } \\
\text { number of times } \\
\text { badge displayed on } \\
\text { other sites } \\
\text { number of "likes" }\end{array}$ \\
\hline Microblogging & $\begin{array}{l}\text { number of followers } \\
\text { number of tweets about } \\
\text { the brand } \\
\text { valence of tweets }+/-\end{array}$ & $\begin{array}{l}\text { number of followers } \\
\text { number of @replies }\end{array}$ & number of retweets \\
\hline $\begin{array}{ll}\text { Video and } \\
\text { Photosharing }\end{array}$ & $\begin{array}{l}\text { number of } \\
\text { videos/photos uploaded } \\
\text { number of views of } \\
\text { video/photo } \\
\text { valence of video/photo } \\
\text { rating +/- }\end{array}$ & $\begin{array}{l}\text { number of page views } \\
\text { number of replies } \\
\text { number of comments } \\
\text { number of forums created } \\
\text { number of subscribers }\end{array}$ & $\begin{array}{l}\text { number of } \\
\text { embeddings } \\
\text { number of incoming } \\
\text { links } \\
\text { number of } \\
\text { references in mock- } \\
\text { ups or derived work } \\
\text { number of times } \\
\text { published in other } \\
\text { social media and } \\
\text { offline } \\
\text { number of "likes" }\end{array}$ \\
\hline
\end{tabular}


Since the upcoming of social media consumers have been able to express and disseminate their knowledge and experiences about products and services faster. Owyang und Lovett (2010) suggest some key performance indicators to measure the audience engagement, conversation reach or advocacy promotion.

\section{Share of Voice $=\frac{\text { Brand Mentiors }}{\text { Tctal Mentions }\left(\text { Brand }+ \text { Competitor } A_{t} B, C, \ldots n\right)}$}

(Owyang und Lovett, 2010)

"Share of Voice" is a competitive metric, relating the number of brand mentions in social channels to the total number of all brand mentions. "Share of Voice" should be segmented by channel to identify which social media channels have the greatest impact.

Audience Engagement $=\frac{\text { Comments }+ \text { Shares }+ \text { Trahsbacks }}{\text { Total Views }}$

(Owyang und Lovett, 2010)

By taking the proportion of active visitors (i.e. those who actively participate in the communication) into account, the "Audience Engagement" can help to identify the impact of specific marketing initiative or set of actions. Quite similar is the total conversation reach, a relative percentage of the number of unique participants in the conversation over the total exposed audience.

In the future the internet will connect an even greater number of users and critical information infrastructures. However, why do companies suddenly talk about sensitive data that used to be discussed behind closed curtains before, particularly when the competitors were listening around the corner? Advertisement loses its power and influence, even though it is still about merchandising a product innovation. But, in the internet a recommendation is only a click away and people are talking anyway. Communication processes, engaging prospects and developing these into satisfied customers has reached a complexity that cannot be explained with conventional knowledge and measures. Interactions with customers in real time amplify customer relationship, whereas data leakage or legal implications can impede the company's growth.

Social media sites can also enhance customer support and service. Support inquiries that are resolved directly through social media sites can potentially decrease support costs. Measuring online customer support metrics is as essential as offline KPI's.

The "Issue Resolution Rate" demonstrates the percentage of customer service inquiries that were resolved using social media channels. An implicit factor is that the inquiries have to be resolved satisfactorily, which has to be tested by other means.

Issue Resolution Rate $=\frac{\text { Total Number Issues Rasolved Satisfactorily }}{\text { Total Number of Service Issues }}$ (Owyang und Lovett, 2010)

Depending on the goal, different key metrics for social media applications can help to identify the impact of the activities. The adequate type of key metrics for social media applications to identify the impact of the activities depends on the goal/aim of the company. The basis of the chart by Hoffmann and Fodor (2010) (see Table 2) was scrutinized and completed with metrics obtained by interviews. 20 marketing managers of different industries in Austria were interrogated about metrics they use in their companies and about which metrics they consider useful monitoring in the future. The interviews showed that less than half of the managers use social media tools on a regular basis and even fewer monitor their activities. Therefore, technical students were asked which metrics are of significance to their social media activities and whether they think that these data can be adopted in entrepreneurial application. In principal individuals and companies connect with one another for the same reason. People expect or hope to receive an advantage through the network. Since it is within human nature that actors (either individuals or companies) seek 
to fulfill their needs, they usually do not rest still until having reached their aims. But how can one obtain what he/she was yearning for when he/she never knows (or does not care) if it is unclear how to determine the actual position. It might also be possible that the goal has already been reached. Hence, as mentioned before, it is essential for marketing managers or CEOs first need to define a strategic goal for social media activities or marketing activities in general, and preferably also a business objective. The company, as a unit, has to walk in the same direction, knowing where they are heading. After defining the goals, the company has to decide which social media platform to implement and use. The expert interviews also showed that many Austrian marketers lack a specific strategy for social media usage. If the goal is to increase customer satisfaction the number of minutes the firm is nice to customers be measured. On the other hand, the number of positive comments or posts can indicate the level of satisfaction. Nevertheless, not only the number but also the manner of the comment or post is relevant; a very difficult data to measure indeed.

\section{Sentment Ratio $=\frac{\text { Positive }- \text { Neutral }- \text { Negative Brand Mentions }}{\text { All Brand Mentions }}$}

(Owyang und Lovett, 2010)

Based on the mood barometer percentage of positive, neutral or negative mentions about the corporate brand, the product or the service can be calculated by the $n$ the number of mentions within a certain time period.

\section{Cross Channel}

The level of professionalism and effectiveness of the company's activities depends largely on the expertise of the responsible person. This statement is also applicable to social media activities. Therefore, it is not surprising that U.S. companies have already recognized the importance of the position of a social media manager who, in the best case, combines personal interest in social media with expertise in online communication and tracking methods. However, social media is not a toolbox, but a new set of technologies and concepts. It is not a standalone tool, but has to be integrated into the existing marketing strategy. Purchases nowadays are not only made through a single channel. A McKinsey study (2007) showed that offline purchase can be influenced by online research. The DEI Worldwide study (2008) examined the impact of social media on customer behavior and revealed that $70 \%$ of the consumers visited a social media site to get information. Based on this information $49 \%$ of these customers purchased. However, offline activity can also lead to online purchase. Customers and friends recommend products, print media or $\mathrm{TV}$ commercials brand a product or company, or refer to the web site or online store. Some customers prefer to examine the products physically (in a store) before buying them online. Fig.1 shows the percentage of touch points converted to sales.

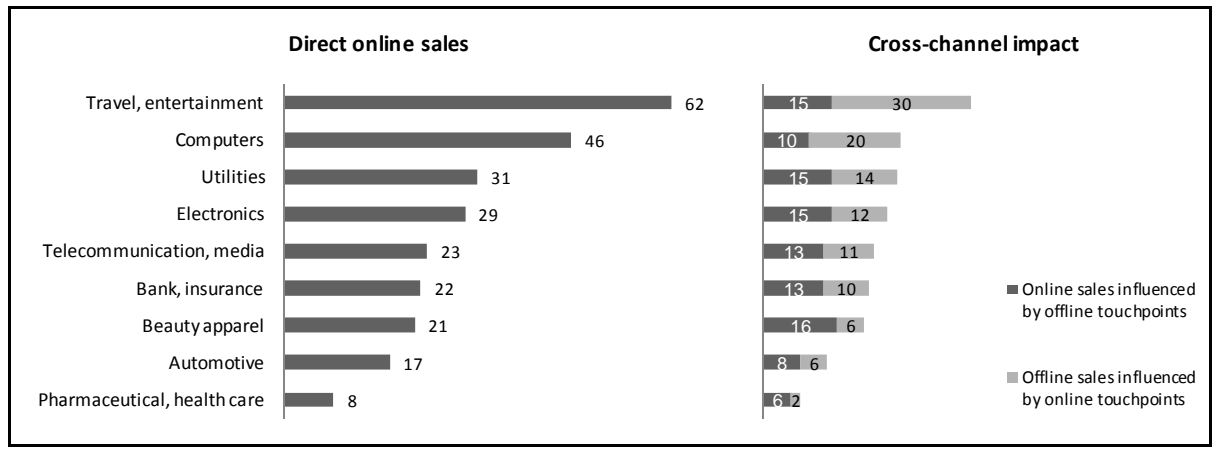

Fig 4. Cross-Channel Impact (Mckinsey Study, 2007) 
It becomes clear that concentrating on one channel and only measuring direct online sales can be dangerous and might lead to a lack of effectiveness of the total impact. The internet and Web 2.0 are great tools for branding a product or a company, communicating with customers and building up relationships, but they cannot replace traditional media. Rather than altered, the marketing mix has enlarged.

\section{Conclusion and Further Research}

This paper has listed several ways of measuring social media activities, based on a review of the literature and on the analysis of expert interviews. The illustrated table of key metrics for social media applications gives a useful overview of metrics assigned to the most common used social media platforms (i.e. social networking sites, blogs, micro blogging, social bookmarking sites and sharing sites). These are only of qualitative nature and do not reflect any return on social media marketing investments. In order to develop a manual for marketers that link the so-called soft metrics (metrics with qualitative objectives) with traditional financial performance measurement indicators, the next step is to investigate the use of social media as well as the monitoring in companies. On the basis of a qualitative study, data of practical usage will be collected and investigated. So far several surveys, mostly of quantitative and only descriptive manner, have been carried out. In the majority of the cases they outline the usage of social media platforms in domestic industries, the allocation of the different tools and platforms as well as the spending on social media marketing investment. Only few studies inquire the usage of social media and even less point out how social media spending is monitored. As a consequence, this lack of measurement techniques will be analyzed. Moreover, the linkage between the different key metrics among each other and the outcome in financial performance measures will be elaborated.
Although social media applications are great tools to communicate with customers, to raise brand awareness or brand engagement, and maybe also to increase sales, it is not a standalone tool. In fact, it should always be combined with traditional media and be used as an add-on to the existing marketing activities. Furthermore, companies should implement social media managers or even social media mission control centers to constantly monitor social media activities and intervene with corrective action when necessary.

\section{References}

Aaker, D. A. (1996). 'Measuring Brand Equity across Products and Markets,' California Management Review, 38 (3), 102-120.

Ambler, T. \& Kokkinaki, F. (1997). "Measures of Marketing Success," Journal of Marketing Management, 13, 665-678.

Ambler, T., Kokkinaki, F. \& Puntoni, S. (2004). "Assessing Marketing Performance: Reasons for Metrics Selection," Journal of Marketing Management, 20, 475-498.

Ambler, T. \& Riley, D. (2000). 'Marketing Metrics: A Review of Performance Measures in Use in the UK and Spain,' Working Paper No. 00-901, London Business School, Centre for Marketing.

Barwise, P. \& Farley, J. U. (2004). "Marketing Metrics: Status of Six Metrics in Five Countries," European Management Journal, 22 (3), 257-262.

Bughin, J., Guggenheim Shenkan, A. \& Singer, M. (2008). 'How Poor Metrics Undermine Digital Marketing,' The Mckinsey Quarterly, October 2008.

Clark, B. H. (1999). "Marketing Performance Measures: History and Interrelationships," Journal of Marketing Management, 15, 711-733. 
Cuming, L. (2008). "Engaging Consumers Online, The Impact of Social Media on Purchasing Behavior," DEI Worldwide. [Online]. [Retreived April 4, 2011], http://www.deiworldwide.com/files/DEIStu dy-Engaging\%20ConsumersOnlineSummary.pdf

Davis, J. (2007). Measuring Marketing: 103 Key Metrics Every Marketer Needs. Singapore: John Wiley \& Sons.

Farris, P. W., Bendle, N. T., Pfeifer, P. E. \& Reibstein, D. J. (2006). Marketing Metrics: 50+ Metrics Every Executive Should Master, New Jersey, Wharton School Publishing.

Gruca, T. S. \& Rego, L. L. (2005). "Customer Satisfaction, Cash Flow, and Shareholder Value," Journal of Marketing, 69 (3), 1-18.

Hoffman, D. L. \& Fodor, M. (2010). "Can You Measure the ROI of Your Social Media Marketing?," MIT Sloan Management Review, Fall 2010, Vol. 52, 41-49.

Jason, F. (2008). "What Is the ROI for Social Media?," [Online]. [Retreived April 4, 2011], http://www.socialmediaexplorer.com/social -media-marketing/what-is-the-roi-for-socialmedia/)

Kaplan, R. S. \& Norton, D. P. (1992). "The Balanced Scorecard-Measures That Drive Performance," Harvard Business Review, 70 (1), 71-79.

Keller, K. L. (1993). "Conceptualizing, Measuring and Managing Customer-Based Brand Equity," Journal of Marketing, 57 (1), 1-29.

Kim, W., Joeng, O. R. \& Lee, S. W. (2009). "On Social Web Sites," Information Systems, 35 (2), 215-236.

Kokkinaki, F. \& Ambler, T. (1999). "Market Performance Assessment: An Exploratory Investigation into Current Practice and the Role of Market Orientation," MSI Report, Cambridge, MA, Marketing Science Institute, 98-132.
Likely, F., Rockland, D. \& Weiner, M. (2006). "Perspectives on the ROI of Media Relations Publicity Efforts," The Institute of Public Relations, May 2006.

Llonch, J., Eusebio, R. \& Ambler, T. (2002).

"Measures of Marketing Success: A Comparison between Spain and UK," European Management Journal, 20 (4), 414-422.

O’Reilly, T. (2005). "What Is Web 2.0," [Online]. [Retreived September 19, 2010], http://oreilly.com/lpt/a/6228

Owyang, J. \& Lovett, J. (2010). "Social Marketing Analytics- A New Framework for Measuring Results in Social media," [Online]. Altimetergroup. [Retreived April 4, 2011], http://www.slideshare.net/jeremiah_owyan g/altimeter-report-social-marketinganalytics

Petersen, J. A., McAlister, L., Reibstein, D. J., Winer, R. S., Kumar, V. \& Atkinson, G. (2009). "Choosing the Right Metrics to Maximize Profitability and Shareholder Value," Journal of Retailing, 85 (1), 95-111.

Powell, G. R. (2002). Return on Marketing Investment: Demand More from Your Marketing and Sales Investments, Atlanta: RPI Press.

Reichheld, F. F. (2003). "The One Number You Need to Grow," Harvard Business Review, December 2003.

Safko, L. (2010). The Social Media Bible. Tactics, Tools, and Strategies for Business Success, John Wiley \& Son, Second Edition, 9.

Sampaio, C. H., Simões, C., Gattermann Perin, M. \& Almeida, A. (2011). "Marketing Metrics: Insights from Brazilian Managers," Industrial Marketing Management, 40, 8-16.

Seggie, S. H., Cavusgil, E. \& Phelan, S. E. (2007). "Measurement of Return on Marketing Investment: A Conceptual Framework and the Future of Marketing 
Journal of Internet Social Networking \& Virtual Communities 14

Metrics," Industrial Marketing Management, 36 (6), 834-841.

Streukens, S., Van Hoesel, S \& De Ruyter, K. (2011). "Return on Marketing Investments in B2B Customer Relationships: A DecisionMaking and Optimization Approach," Industrial Marketing Management, 40, 149-161.

Travers, J. \& Milgram, S. (1969). "An Experimental Study of the Small World Problem," Sociometry, Vol. 32 (4), 425-443.

Warr, W. A. (2008). "Social Software: Fun and Games, or Business Tools?," Journal of Information Science, 34 (4), 591-604. 